\title{
CLINICAL AND ECONOMIC OUTCOMES OF NEW ORAL ANTICOAGULANTS IN ORTHOPAEDICS
}

\author{
Dragana Lakic ${ }^{1}$, Jovana Travica ${ }^{1}$, Marina Odalovic ${ }^{1}$, Ivana Tadic ${ }^{1}$
}

${ }^{1}$ Department for Social Pharmacy and Pharmacy Legislation, University of Belgrade - Faculty of Pharmacy, Serbia

\section{KLINIČKI I EKONOMSII ISHODI PRIMENE NOVIH ORALNIH ANTIKOAGULANASA U ORTOPEDIJI \\ Dragana Lakić ${ }^{1}$, Jovana Travica ${ }^{1}$, Marina Odalović ${ }^{1}$, Ivana Tadić ${ }^{1}$ \\ Katedra za socijalnu farmaciju i farmaceutsko zakonodavstvo, Univerzitet u Beogradu - Farmaceutski fakultet, Srbija}

\begin{abstract}
Venous thromboembolism, including pulmonary embolism and deep vein thrombosis, is a significant factor in morbidity and mortality of patients. New oral anticoagulants, such as apixaban, dabigatran, and rivaroxaban, have recently demonstrated their safety and efficacy in patients undergoing major orthopaedic surgery. Selection of the appropriate drug should be adjusted according to patient needs. Major bleeding is rare with new oral anticoagulants and is comparable with the bleeding rate associated with low-molecular-weight heparins. Clinical data indicate that therapy with apixaban and rivaroxaban was more effective compared to enoxaparin, while dabigatran has a similar efficacy to enoxaparin. Cost-effectiveness studies of new oral anticoagulants showed that these medicines offer higher efficacy with acceptable costs for the healthcare system, even saving costs in certain cases. Clinical practice in Serbia reflects considerably more frequent use of traditional anticoagulant medication therapy compared to new oral anticoagulants.
\end{abstract}

Keywords: new oral anticoagulant, orthopaedic surgery, clinical outcomes, economic outcomes

\section{SAŽETAK}

Venska tromboembolija, koja uključuje plućnu emboliju i duboku vensku trombozu, predstavlja značajan faktor morbiditeta i mortaliteta pacijenata. Novi oralni antikoagulansi, poput apiksabana, dabigatrana i rivaroksabana, su nedavno pokazali svoju bezbednost $i$ efikasnost kod pacijenata koji se podvrgavaju velikim ortopedskim intervencijama. Izbor odgovarajućeg leka treba prilagoditi individualnim potrebama pacijenta. Velika krvarenja su relativno retka u toku primene novih oralnih antikoagulanasa $i$ uporedivi su sa stopom krvarenja prilikom primene nisko-molekularnih heparina. Klinički podaci ukazuju da je terapija apiksabanom i rivarokabanom efikasnija u odnosu na enoksaparin, dok dabigatran ima slične efekte kao enoksaparin. Troškovna isplativost novih oralnih antikoagulanasa potvrduje veću efikasnost sa prihvatljivim troškovima za zdravstveni sistem, u nekim slučajevima čak $i$ sa uštedama.

Ključne reči: novi oralni antikoagulansi, ortopedska hirurgija, klinički ishodi, ekonomski ishodi

\section{INTRODUCTION}

Venous thromboembolism (VTE), which includes pulmonary embolism (PE) and deep vein thrombosis (DVT), is a significant factor in morbidity and mortality of patients. The incidence of VTE in the world is approximately 1 person per 1,000 in one year, while 180000 deaths are annually recorded in the United States as a result of VTE (1-3). In Europe, 1.66 million cases of non-fatal symptomatic VTE are recorded per year (4). In the majority of hospitalized patients, clot predisposing factors are present, especially in orthopaedic and surgical patients. High risk of VTE is present in patients who are undergoing knee and/or hip surgery. According to clinical studies, the percentage of venography that confirmed DVT in major joint surgery without the use of prophylaxis is between $40 \%$ and $85 \%(5,6)$. Therefore, pharmacological prophylaxis represents a very important factor in the reduction of morbidity and mortality in patients who are undergoing major orthopaedics surgeries. For many years, warfarin and lowmolecular-weight heparins were applied with prophylactic purposes. However, all of these drugs have certain limitations in modern clinical practice (7). In the last several years, several new oral anticoagulants were approved for the prevention of VTE in these patients (8). 
CLINICAL OUTCOMES OF NEW ORAL ANTICOAGULANTS

New oral anticoagulants (NOA), such as apixaban, dabigatran, and rivaroxaban, have recently demonstrated their safety and efficacy. These NOAs are currently considered to be an alternative to warfarin. The new oral anticoagulants have a predictable and stable pharmacokinetics with low potential for interaction. These medicines do not need continuous monitoring or frequent adjustment of dose, and there is a low probability that they will cause intracranial bleeding (8). The development of NOA that is used in orthopaedic surgery has great clinical significance.

\section{Apixaban}

Apixaban is a direct and reversible factor Xa inhibitor (9). Studies for the prevention of DVT in animal models showed that apixaban has adequate efficiency. The recommended daily dose is $2.5 \mathrm{mg}$ orally twice daily. To minimize undesirable outcomes, the starting dose should be initiated 12-24 $\mathrm{h}$ after the surgery (10). Apixaban has good bioavailability, low clearance and low potential for interactions with other drugs and is eliminated by urine, bile and faeces (11). In 2011, apixaban was approved in Europe for prevention of DVT in patients who had elective hip or knee replacement surgery. For this indication, apixaban is available in more than 50 countries (12). Use of apixaban in the prevention of DVT is supported by 3 clinical trials, known as the ADVANCE clinical studies (13-15). The studies were designed to assess the safety and efficacy of apixaban in more than 11,500 patients, of which 5770 patients were on apixaban and 5,755 patients were on enoxaparin.

ADVANCE-1 (13) and ADVANCE-2 (14) studies have evaluated the use of apixaban in patients who underwent elective knee replacement surgery, while the ADVANCE-3 study (15) evaluated the effects in patients who underwent elective hip replacement surgery. During Phase III in all three ADVANCE studies, the primary efficacy endpoint composed of all VTE and all-cause mortality were followed, while for the safety assessment, the occurrence of bleeding during treatment was followed. Apixaban showed a statistically superior reduction in the primary endpoint compared to enoxaparin in both elective hip or knee replacement surgery. The risk of major bleeding after administration of apixaban was significantly lower compared to enoxaparin $(\mathrm{OR}=0.55 ; 95 \% \mathrm{CI} 0.32,0.96)(16)$. Apixaban parameters of efficacy and safety compared to warfarin have been published in 2012, and these results are even more convincing compared to enoxaparin. Incidence of VTE and all-cause mortality were $9 \%$ in the apixaban group compared to $26.6 \%$ in the warfarin group. The incidence of bleeding was comparable between groups (17).

\section{Dabigatran}

Dabigatran is a direct thrombin inhibitor, which consequently results in antiplatelet activity. Dabigatran is indicated for the primary prevention of VTE in adult patients undergoing elective total hip or knee replacement surgery. Key studies have shown that dabigatran has similar efficacy and safety as enoxaparin. Compared to vitamin $\mathrm{K}$ antagonists (warfarin), dabigatran provides a number of advantages, including the lack of interaction with food, oral administration, no risk of thrombocytopenia and a predictable anticoagulant effect. Dabigatran clinical trials in the US and Europe estimated its importance for prevention of thromboembolic events. In 2008, dabigatran was approved by the EMA for the primary prevention of VTE in patients who underwent total hip or knee replacement (18). The results of post-marketing studies (RE-study) additionally confirmed the validity of dabigatran use in prevention of VTE in orthopaedic patients compared to lowmolecular-weight heparin (19).

Later meta-analysis of the RE-MODEL, RE-NOVATE and RE-MOBILIZE studies showed that there were no significant differences in efficacy between dabigatran and enoxaparin, including the total VTE and mortality (20).

The latest study from 2015 estimated the safety and efficacy of dabigatran for the prevention of VTE in patients undergoing total hip or knee replacement, but for those previously treated with low-molecular-weight heparins. The authors concluded that switching patients from low-molecular-weight heparin to dabigatran is a safe and effective pharmacotherapy. In addition, switching from a subcutaneous to an oral therapy offered an easier, less expensive, and more convenient route of administration for the patients and healthcare professionals (21). As with the other NOA, the major concerns regarding the safety profile are the frequency and severity of bleeding. In all of the abovementioned studies, the safety of dabigatran was comparable to that of the low-molecular-weight heparins. In the RE-studies, a similar safety profile of dabigatran and warfarin for risk of major bleeding was observed. The incidence of relevant bleeding, especially cerebral bleeding, was low in patients who were treated with dabigatran compared to other anticoagulants in the Phase III study. This supports once more a desirable safety profile of dabigatran (22).

\section{Rivaroxaban}

Rivaroxaban is a direct and selective factor Xa inhibitor (23). Rivaroxaban is approved in the United States and the European Union for the prevention of VTE in patients undergoing a total hip or knee replacement (24). In four RECORD studies, which included more than 12,500 patients, the efficacy of rivaroxaban was superior compared to enoxaparin in major orthopaedic surgery (25-28). The incidence of DVT and non-fatal PE was significantly lower in the rivaroxaban group compared to the enoxaparin group, regardless of whether it was an elective knee (30\% to $50 \%$ reduction in incidence of VTE) or hip surgery (decreased for more than 70\%). In addition, the safety profiles of these drugs were very similar. The latest international study XAMOS (Xarelto ${ }^{\circ}$, use in prophylaxis of surgical venous thromboembolism after major orthopaedic surgery 
of the hip or knee) intended to provide additional information on the assessment of the benefits and risks of use of rivaroxaban compared with standard VTE prophylaxis. More than 17,000 patients from 37 countries participated in this study between February 2009 and August 2011. Rivaroxaban was associated with a significantly lower rate of thromboembolic events. The relevant bleeding rate was similar between the two groups. Therefore, it was concluded that the non-intervention study XAMOS confirmed the results of the RECORD clinical trial (29).

\section{ECONOMIC OUTCOMES OF NEW ORAL ANTI- COAGULANTS}

The cost-effectiveness of therapy certainly plays an important role in the selection of an appropriate anticoagulant drug. There is a continued need for saving time and money in addition to maintaining the simplicity of the drug application. Use of aspirin, due to its low price and simple administration, is shown to be a good alternative to low-molecular-weight heparins after hip or knee surgery (30). New oral anticoagulants play a significant role in reducing cost when compared to low-molecular-weight heparins (31).

\section{Apixaban}

A Canadian study analysed the cost-effectiveness of apixaban compared to enoxaparin in prophylactic therapy for DVT in patients undergoing total hip or knee replacement. In the study, two economic models, decision tree and Markov model, were combined. The results showed that apixaban was better (more effective and less expensive) than enoxaparin in treating patients undergoing major orthopaedic surgery. Savings of USD180 to USD270 per patient could be expected with apixaban treatment compared to enoxaparin treatment (32). Budgetary impact for the Spanish health system of apixaban prophylaxis of VTE in patients undergoing total knee or hip replacement showed that the inclusion of apixaban did not have any positive monetary impact, but led to a reduction in the rate of VTE and bleeding (33). In the British guidance of apixaban, it is stated that apixaban was more clinically effective and less expensive than enoxaparin; however, it was also concluded that there was insufficient clinical evidence to determine whether apixaban was more or less clinically effective than another NOA (34).

\section{Dabigatran}

For in- or out-patients in need for thromboprophylaxis after orthopaedic surgery, the total cost of enoxaparin administration becomes higher than that of dabigatran, making dabigatran therapy cost-effective for these groups of patients (22). The British guidance from 2008 concluded that dabigatran was likely to be of equivalent clinical and cost effectiveness to low-molecular-weight heparins for the prevention of VTE but had advantages in route of ad- ministration since it did not have a need for monitoring, and demonstrated a reduction in administration costs and better adherence to treatment (35).

\section{Rivaroxaban}

The cost-effectiveness of rivaroxaban was assessed in several countries based on the data from the RECORD studies. In the Germany study, prophylaxis with rivaroxaban reduced the number of VTE events and provided cost savings (EUR27.3 saving per patient treated) compared with enoxaparin (36). A cost-effectiveness study conducted for the Swedish health system showed that in patients undergoing total hip replacement, the extended prophylaxis for 35 days with rivaroxaban was cost-effective compared to 14 days of prophylaxis with enoxaparin or dalteparin. In total knee replacement patients, 14 days of rivaroxaban treatment was more effective and less expensive than 14 days of low-molecular-weight heparin prophylaxis for VTE (37).

\section{CLINICAL PRACTICE IN SERBIA}

Despite the availability of NOA, the dominant place in clinical practice in Serbia still use low-molecular-weight heparins and older anticoagulants, such as warfarin or acenocoumarol. The main reason for this is the limited availability of NOA in Serbia. Although all three NOAs have marketing authorization in Serbia, only dabigatran and rivaroxaban are on the reimbursement list (38). The supply of these two drugs is based on a centralized public procurement procedure.

Table 1 shows the IMS (IMS Health, IMS Health Database) consumption data of pharmacological agents that are used in the prophylaxis of VTE during the four-year period (2012-2015). All data are presented according to the original packaging. A low-molecular-weight heparin, nadroparin, had the highest consumption over all four years.

Figure 1 shows the consumption of drugs used in the prophylaxis of VTE according to the WHO/DDD methodology. The defined daily dose (DDD) is a unit of measurement that was proposed by the World Health Organization (WHO). DDD is defined as "the assumed average maintenance dose per day for a drug used for its main indication in adults." Unit DDD represents the average dose for an adult weighing $70 \mathrm{~kg}$ in primary indication of the ATC classification system. This dose is independent from the price of the pharmaceutical form, while the concentration is in a single form and size of the package (39). The number of inhabitants each year is taken from the website of the Republic Institute for Statistics (40).

The highest consumption of pharmacotherapy for prophylaxis of VTE was recorded during 2015 with a total 8.21 DDD/1000 inhabitants/day. During the four years, the largest share in the consumption belonged to warfarin (41\% in 2014; 58\% in 2013). During the observed period, NOA consumption growth was recorded. 
Table 1. Consumption of drugs used in the prophylaxis of VTE during the period 2012 - 2015 (IMS Health Database)

\begin{tabular}{|c|c|c|c|c|c|}
\hline INN & Package, pharmaceutical form, strength & 2012 & 2013 & 2014 & 2015 \\
\hline warfarin & 30 tablets, $5 \mathrm{mg}$ & 372,867 & 404,686 & 325,543 & 461,714 \\
\hline acenocoumarol & 20 tablets, $4 \mathrm{mg}$ & 134,614 & 103 & 163,665 & 253,596 \\
\hline heparin & 5 ampules, $5000 \mathrm{IU} / 0.25 \mathrm{ml}$ & 36,154 & 35,315 & 4,850 & 7 \\
\hline heparin & 5 ampules, $5000 \mathrm{IU} / \mathrm{ml}$ & 28,849 & 34,158 & 35,743 & 46,633 \\
\hline heparin & 10 ampules, $25000 \mathrm{IU} / 5 \mathrm{ml}$ & 27,828 & 34,890 & 32,510 & 31,638 \\
\hline dalteparin & 10 prefilled syr., $2500 \mathrm{IU} / 0.2 \mathrm{ml}$ & 15,831 & 19,168 & 13,550 & 13,880 \\
\hline dalteparin & 10 prefilled syr., $5000 \mathrm{IU} / 0.2 \mathrm{ml}$ & 15,061 & 12,834 & 14,478 & 10,660 \\
\hline dalteparin & 10 prefilled syr., $10000 \mathrm{IU} / \mathrm{ml}$ & 60 & 74 & & 50 \\
\hline enoxaparin & 2 prefilled syr., $2000 \mathrm{IU} / 0.2 \mathrm{ml}$ & 24,552 & 27,528 & 4,048 & 27 \\
\hline enoxaparin & 10 prefilled syr., $2000 \mathrm{IU} / 0.2 \mathrm{ml}$ & & 3 & 3,499 & 3,679 \\
\hline enoxaparin & 2 prefilled syr., $4000 \mathrm{IU} / 0.4 \mathrm{ml}$ & 103,176 & 117,359 & 10,162 & 3 \\
\hline enoxaparin & 10 prefilled syr., $4000 \mathrm{IU} / 0.4 \mathrm{ml}$ & & 807 & 23,925 & 27,017 \\
\hline enoxaparin & 2 prefilled syr., $6000 \mathrm{IU} / 0.6 \mathrm{ml}$ & 72,912 & 84,697 & 5,621 & \\
\hline enoxaparin & 10 prefilled syr., $6000 \mathrm{IU} / 0.6 \mathrm{ml}$ & & 548 & 18,659 & 20,696 \\
\hline enoxaparin & 2 prefilled syr., $8000 \mathrm{IU} / 0.8 \mathrm{ml}$ & 47,661 & 55,532 & 989 & 1 \\
\hline enoxaparin & 10 prefilled syr., $8000 \mathrm{IU} / 0.8 \mathrm{ml}$ & & 402 & 9,766 & 10,455 \\
\hline nadroparin & 10 prefilled syr., $2850 \mathrm{IU} / 0.3 \mathrm{ml}$ & 118,549 & 131,788 & 156,425 & 161,072 \\
\hline nadroparin & 10 prefilled syr., $3800 \mathrm{IU} / 0.4 \mathrm{ml}$ & 20,050 & 26,674 & 30,968 & 42,319 \\
\hline nadroparin & 10 prefilled syr., $5700 \mathrm{IU} / 0.6 \mathrm{ml}$ & 41,299 & 52,753 & 64,467 & 73,911 \\
\hline reviparin & 10 prefilled syr., $1750 \mathrm{IU} / 0.25 \mathrm{ml}$ & 1.407 & & & \\
\hline reviparin & 10 prefilled syr., $3436 \mathrm{IU} / 0.6 \mathrm{ml}$ & 1,463 & & & \\
\hline fondaparinux & 10 prefilled syr., $2.5 \mathrm{mg} / 0.5 \mathrm{ml}$ & 883 & 1,460 & 1,036 & 1,370 \\
\hline rivoroxaban & 10 tablets, $10 \mathrm{mg}$ & 95 & 860 & 1,944 & 2,577 \\
\hline rivoroxaban & 28 tablets, $15 \mathrm{mg}$ & & 48 & 1,153 & 4,357 \\
\hline rivoroxaban & 42 tablets, $15 \mathrm{mg}$ & & 13 & 76 & 64 \\
\hline rivoroxaban & 28 tablets, $20 \mathrm{mg}$ & & 189 & 2,942 & 8,798 \\
\hline dabigatran & 10 capsules, $110 \mathrm{mg}$ & 102 & 101 & 296 & 236 \\
\hline dabigatran & 30 capsules, $75 \mathrm{mg}$ & 131 & 243 & 356 & 357 \\
\hline dabigatran & 10 capsules, $75 \mathrm{mg}$ & 40 & 254 & 354 & 379 \\
\hline dabigatran & 30 capsules, $110 \mathrm{mg}$ & 93 & 254 & 225 & 316 \\
\hline dabigatran & 60 capsules, $150 \mathrm{mg}$ & & 493 & 4,032 & 9,610 \\
\hline dabigatran & 60 capsules, $110 \mathrm{mg}$ & & 662 & 5,053 & 12,235 \\
\hline
\end{tabular}

Table 2 shows the volume of drugs used in the prevention of VTE, which was obtained through public procurement. The table shows data on an annual basis for 2014 and adjusted data for 2015, considering the different time durations of public procurement.

\section{CONCLUSIONS}

In the future, an increase in the number of hip and knee operations is expected. For this reason, safe and effective prophylaxis is essential to reduce mortality and morbidity related to VTE. The NOAs have the potential to reduce the incidence of VTE after total hip and knee replacement. Therefore, NOAs can contribute to significant savings through the reduction of VTE rate, improved safety and reduced costs of monitoring and administration.

Implementation of NOAs in prophylaxis of VTE is easy and straightforward, but there are specific pharmacological differences between apixaban, rivaroxaban and dabigatran. Selection of the appropriate drug should be adjusted according to the patient needs. Major bleeding is rare with NOA and comparable with the bleeding rate with low-molecular-weight heparins. All NOAs have predictable pharmacokinetics with a short half-life. Clinical data indicate that therapy with apixaban and rivaroxaban was more effective compared to enoxaparin, while dabigatran has a similar efficacy to that of enoxaparin. Cost-effectiveness studies of NOAs showed that these medicines offer higher efficacy with acceptable 
4,0

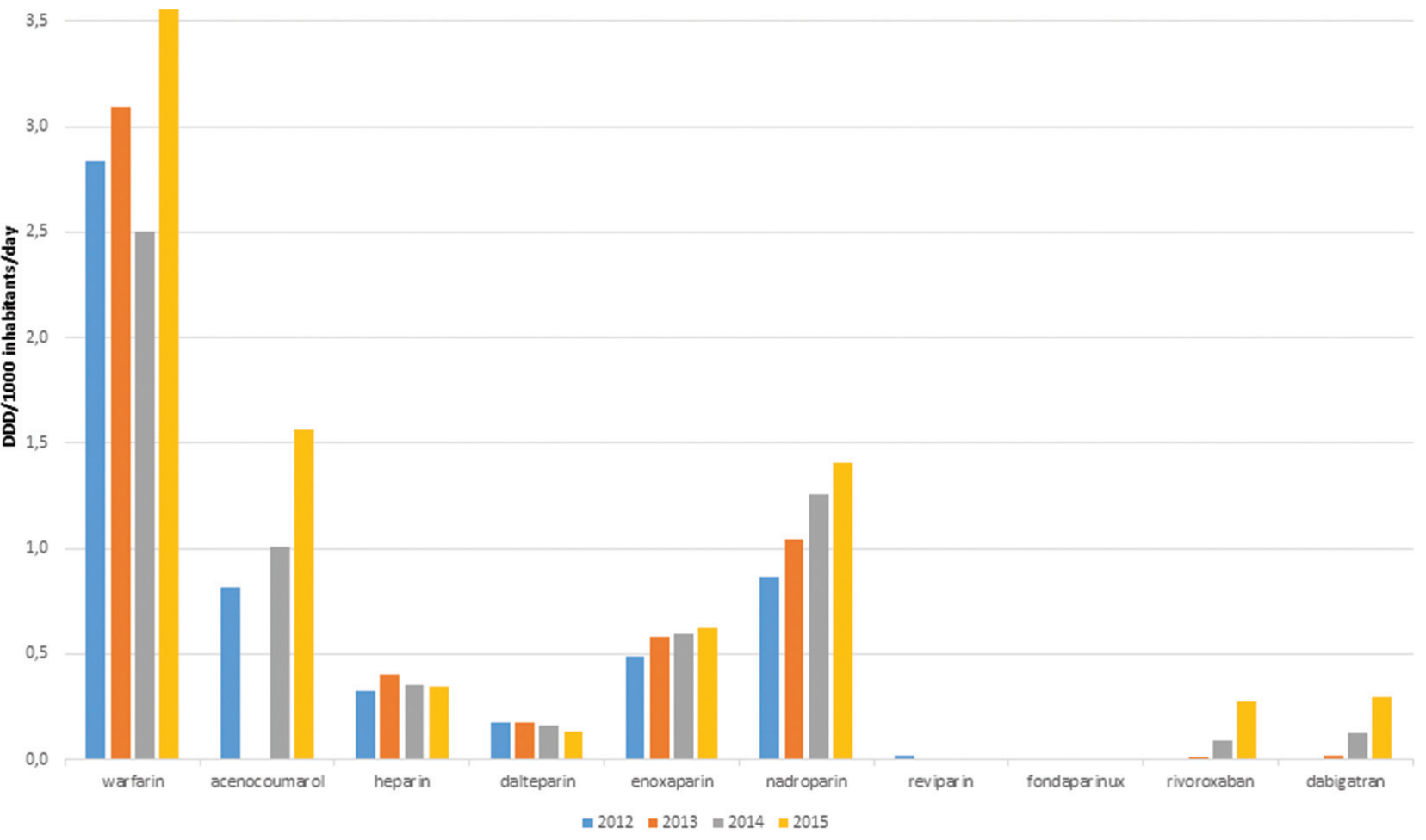

Figure 1. Consumption of drugs used in the prophylaxis of VTE according to the WHO/DDD methodology from 2012 to 2015

Table 2. Consumption of drugs used in the prophylaxis of VTE through centralized public procurement in 2014 and 2015

\begin{tabular}{|l|l|l|l|}
\hline INN & Pharmaceutical form, strength & $\begin{array}{l}\text { Number of unit doses } \\
\text { in 2014 }\end{array}$ & $\begin{array}{l}\text { Number of unit doses } \\
\text { in 2015 }\end{array}$ \\
\hline warfarin & 30 tablets, $5 \mathrm{mg}$ (original pack) & & $140,000^{*}$ \\
\hline acenocoumarol & 20 tablets, $4 \mathrm{mg}$ (original pack) & & $45,250^{*}$ \\
\hline heparin & ampule, 5000IU/0.25 ml & 140,600 & 74,666 \\
\hline heparin & ampule, 5000IU/1 ml & 99,500 & 111,376 \\
\hline heparin & ampule, $25000 \mathrm{IU} / 5 \mathrm{ml}$ & 146,800 & 253,960 \\
\hline dalteparin & prefilled syr., 2500IU/0.2 ml & 119,400 & 200,464 \\
\hline dalteparin & prefilled syr., 5000IU/0.2 ml & 95,600 & 223,664 \\
\hline dalteparin & prefilled syr., 10000IU/ml & 1,000 & 104 \\
\hline enoxaparin & prefilled syr., 2000IU/0.2 ml & 32,700 & 25,096 \\
\hline enoxaparin & prefilled syr., $4000 \mathrm{IU} / 0.4 \mathrm{ml}$ & 154,900 & 160,000 \\
\hline enoxaparin & prefilled syr., 6000IU/0.6 ml & 115,000 & 144,512 \\
\hline enoxaparin & prefilled syr., $8000 \mathrm{IU} / 0.8 \mathrm{ml}$ & 63,600 & 78,400 \\
\hline nadroparin & prefilled syr., $2850 \mathrm{IU} / 0.3 \mathrm{ml}$ & 897,000 & $1,160,808$ \\
\hline nadroparin & prefilled syr., 3800IU/0.4 ml & 139,000 & 229,784 \\
\hline nadroparin & prefilled syr., $5700 \mathrm{IU} / 0.6 \mathrm{ml}$ & 287,000 & 469,776 \\
\hline rivoroxaban & tablet, $10 \mathrm{mg}$ & & 3,000 \\
\hline dabigatran & capsule, $75 \mathrm{mg}$ & & 200 \\
\hline dabigatran & capsule, $110 \mathrm{mg}$ & & 800 \\
\hline
\end{tabular}

* - Refers to the original packaging and not to individual forms (tablet) 
costs for healthcare system and, in certain cases, even presented with savings. NOAs represent an alternative to traditional anticoagulants due to the following advantages: no titration of the dose, low capacity for interactions and no need for monitoring. In that line, NOAs are considered to be effective, acceptable in safety profile and a cost-effective alternative to parenteral pharmacological prophylaxis. Clinical practice in Serbia reflects considerably more frequent use of traditional anticoagulant medication therapy compared to NOA.

\section{Financial support}

The work was financially supported by the Ministry of Education, Science and Technological Development of Republic of Serbia (project No. 175035 and 41012).

\section{REFERENCES}

1. Cushman M. (2007). Epidemiology and Risk Factors for Venous Thrombosis. Semin Hematol. 44(2), 62-9. DOI: 10.1053/j.seminhematol.2007.02.004.

2. Tagalakis V, Patenaude V, Kahn SR, Suissa S. (2013). Incidence of and Mortality from Venous Thromboembolism in a Real-world Population: The Q-VTE Study Cohort. Am J Med. 126(9), 832.e13-21. DOI: 10.1016/j. amjmed.2013.02.024.

3. Goldhaber SZ. (2012). Venous thromboembolism: Epidemiology and magnitude of the problem. Best Pract Res Clin Haematol. 25(3), 235-42. DOI: 10.1016/j. beha.2012.06.007.

4. Cohen AT, Agnelli G, Anderson FA, Arcelus JI, Bergqvist D, Brecht JG, et al. (2007). Venous thromboembolism (VTE) in Europe. The number of VTE events and associated morbidity and mortality. Thromb Haemost. 98(4), 756-64. DOI: 10.1160/TH07-03-0212.

5. Falck-Ytter Y, Francis CW, Johanson NA, Curley C, Dahl OE, Schulman S, Ortel TL, Pauker SG, Colwell CW Jr. (2012). Prevention of VTE in orthopedic surgery patients: antithrombotic therapy and prevention of thrombosis, 9th ed: American College of Chest Physicians evidence-based clinical practice guidelines. Chest 141(2 Suppl), e278S-325S. DOI: 10.1378/ chest.11-2404.

6. Geerts WH, Bergqvist D, Pineo GF, Heit JA, Samama CM, Lassen MR, Colwell CW. (2008). Prevention of venous thromboembolism: American College of Chest Physicians evidence-based clinical practice guidelines (8th Edition). Chest 133(6 Suppl), 381S-453S. DOI: 10.1378/chest.08-0656.

7. Falck-Ytter Y, Warwick D, Dahl OE, Fisher WD; International Surgical Thrombosis Forum. (2008). Orthopaedic thromboprophylaxis: limitations of current guidelines. J Bone Joint Surg Br. 90(2), 127-32. DOI: 10.1302/0301-620X.90B2.20106.
8. Bass AR. (2015). Using new oral anticoagulants in patients undergoing major orthopedic surgery. Curr Rheumatol Rep. 17(4), 25. DOI: 10.1007/s11926-015-0498-z.

9. Eriksson BI, Quinlan DJ, Weitz JI. (2009). Comparative pharmacodynamics and pharmacokinetics of oral direct thrombin and factor Xa inhibitors in development. Clin Pharmacokinet. 48(1), 1-22. DOI: 10.2165/0003088-200948010-00001.

10. Wong PC, Crain EJ, Pinto DJ, Watson CA. (2007). Dose-Dependent Antithrombotic Effects of Apixaban, an Oral Direct Factor Xa Inhibitor, in Prevention and Treatment of Thrombosis in Rabbit Models of Arteriovenous-Shunt and Venous Thrombosis at Doses That Preserve Hemostasis. Blood 110, 933.

11. Wong PC, Pinto DJ, Zhang D. (2011). Preclinical discovery of apixaban, a direct and orally bioavailable factor Xa inhibitor. J Thromb Thrombolysis. 31(4), 47892. DOI: 10.1007/s11239-011-0551-3.

12. Imberti D, Gallerani M, Manfredini R. (2012). Therapeutic potential of apixaban in the prevention of venous thromboembolism in patients undergoing total knee replacement surgery. J Thromb Thrombolysis. 34(2), 208-13. DOI: 10.1007/s11239-012-0716-8.

13. Lassen MR, Raskob GE, Gallus A, Pineo G, Chen D, Portman RJ. (2009). Apixaban or enoxaparin for thromboprophylaxis after knee replacement. N Engl J Med. 361(6), 594-604. DOI: 10.1056/NEJMoa0810773.

14. Lassen MR, Raskob GE, Gallus A, Pineo G, Chen D, Hornick P and the ADVANCE-2 investigators. (2010). Apixaban versus enoxaparin for thromboprophylaxis after knee replacement (ADVANCE-2): a randomised double-blind trial. Lancet 375, 807-15. DOI: 10.1016/ S0140-6736(09)62125-5.

15. Lassen MR, Gallus A, Raskob G, Pineo G, Chen D, Ramirez LM. (2010). Apixaban versus enoxaparin for thromboprophylaxis after hip replacement. N Engl J Med. 363(26), 2487-98. DOI: 10.1056/NEJMoa1006885.

16. Huang J, Cao Y, Liao C, Wu L, Gao F. (2011). Apixaban versus enoxaparin in patients with total knee arthroplasty: a meta-analysis of randomized trials. Thromb Haemost. 105(2), 245-53. DOI: 10.1160/ TH10-08-0552.

17. Werth S, Halbritter K, Beyer-Westendorf J. (2012). Efficacy and safety of venous thromboembolism prophylaxis with apixaban in major orthopedic surgery. Ther Clin Risk Manag. 8, 139-47. DOI: 10.2147/TCRM.S24238.

18. Eriksson BI, Dahl OE, Buller HR, et al. (2005). A new oral direct thrombin inhibitor, dabigatran etexilate, compared with enoxaparin for prevention of thromboembolic events following total hip or knee replacement: the BISTRO II randomized trial. Thromb Haemost 3(1), 103-11. DOI: 10.1111/j.1538-7836.2004.01100.x.

19. Eriksson BI, Dahl OE, Huo MH, et al. (2011). Oral dabigatran versus enoxaparin for thromboprophylaxis after primary total hip arthroplasty (RE-NOVATE II). A randomised, double-blind, non-inferiority trial. Thromb Haemost. 105(4), 721-9. DOI: 10.1160/TH10-10-0679. 
20. Wolowacz SE, Roskell NS, Plumb JM, Caprini JA, Eriksson BI. (2009). Efficacy and safety of dabigatran etexilate for the prevention of venous thromboembolism following total hip or knee arthroplasty. A meta-analysis. Thromb Haemost. 101(1), 77-85. DOI: 10.1160/ TH08-07-0493.

21. Wurnig C, Clemens A, Rauscher H, Kleine E, Feuring M , Windhager R, Grohs J. (2015). Safety and efficacy of switching from low molecular weight heparin to dabigatran in patients undergoing elective total hip or knee replacement surgery. Thromb J. 13, 37. DOI: 10.1186/ s12959-015-0066-9.

22. Schulman S, Majeed A. (2012). The Oral Thrombin Inhibitor Dabigatran: Strengths and Weaknesses. Semin Thromb Hemost. 38(1), 7-15. DOI: $10.1055 / \mathrm{s}-$ 0031-1300946.

23. Mismetti P, Laporte S. (2008). Rivaroxaban: clinical pharmacology. Ann Fr Anesth Reanim. 27 (Suppl 27), S16-S21. DOI: 10.1016/S0750-7658(08)75142-6.

24. Steffel J, Luscher TF. (2009). Novel anticoagulants in clinical development: focus on factor $\mathrm{Xa}$ and direct thrombin inhibitors. J Cardiovasc Med (Hagerstown). 10(8), 616-23. DOI: 10.2459/JCM.0b013e32832edac0.

25. Eriksson BI, Borris LC, Friedman RJ, et al. (2008). Rivaroxaban versus enoxaparin for thromboprophylaxis after hip arthroplasty. N Engl J Med. 358(26), 2765-75. DOI: 10.1056/NEJMoa0800374.

26. Kakkar AK, Brenner B, Dahl OE, et al. (2008). Extended duration rivaroxaban versus short-term enoxaparin for the prevention of venous thromboembolism after total hip arthroplasty: a double-blind, randomised controlled trial. Lancet 372(9632), 31-9. DOI: 10.1016/ S0140-6736(08)60880-6.

27. Lassen MR, Ageno W, Borris LC, et al. (2008). Rivaroxaban versus enoxaparin for thromboprophylaxis after total knee arthroplasty. N Engl J Med. 358(26), 2776-86. DOI: 10.1056/NEJMoa076016.

28. Turpie AG, Lassen MR, Davidson BL, et al. (2009). Rivaroxaban versus enoxaparin for thromboprophylaxis after total knee arthroplasty (RECORD 4): a randomised trial. Lancet 373(9676), 1673-80. DOI: 10.1016/S01406736(09)60734-0.

29. Turpie AG, Haas S, Kreutz R, et al. (2014). A non-interventional comparison of rivaroxaban with standard of care for thromboprophylaxis after major orthopaedic surgery in 17,701 patients with propensity score adjustment. Thromb Haemost. 111(1), 94-102. DOI: 10.1160/TH13-08-0666.

30. Anderson DR, Dunbar MJ, Bohm ER, et al. (2013). Aspirin versus low-molecular-weight heparin for extended venous thromboembolism prophylaxis after total hip arthroplasty: a randomized trial. Ann Intern Med. 158(11), 800-6. DOi: 10.7326/0003-4819-158-11201306040-00004.

31. Nutescu EA. (2013). Pharmacoeconomic implications of thromboprophylaxis with new oral anticoagulants after total hip or knee replacement in the USA. Expert Opin Pharmacother. 14(4), 525-34. DOI: 10.1517/14656566.2013.774374.

32. Revankar N, Patterson J, Kadambi A, Raymond V, El-Hadi W. (2013). A Canadian study of the cost-effectiveness of apixaban compared with enoxaparin for postsurgical venous thromboembolism prevention. Postgrad Med. 125(4), 141-53. DOI: 10.3810/ pgm.2013.07.2686.

33. Arrayas IG, Fernandez CS, Cerezo J G, Nicolás L B, Salas-Cansado M, Rubio-Terres C. (2012). Budgetary impact for the National Health System of apixaban prophylaxis of venous thromboembolism in patients undergoing total knee or hip replacement. Rev Esp Salud Publica. 86(6), 601-12. DOi: 10.4321/S113557272012000600006.

34. NICE. (2012). Apixaban for the prevention of venous thromboembolism after total hip or knee replacement in adults. NICE technology appraisal guidance [TA245].

35. NICE. (2008). Dabigatran etexilate for the prevention of venous thromboembolism after hip or knee replacement surgery in adults. NICE technology appraisal guidance [TA157].

36. Zindel S, Stock S, Müller D, Stollenwerk B. (2012). A multi-perspective cost-effectiveness analysis comparing rivaroxaban with enoxaparin sodium for thromboprophylaxis after total hip and knee replacement in the German healthcare setting. BMC Health Serv Res. 12, 192. DOI: $10.1186 / 1472-6963-12-192$.

37. Ryttberg L, Diamantopoulos A, Forster F, Lees M, Fraschke A, Björholt I. (2011). Cost-effectiveness of rivaroxaban versus heparins for prevention of venous thromboembolism after total hip or knee surgery in Sweden. Expert Rev Pharmacoecon Outcomes Res. 11(5), 601-15. DOI: 10.1586/erp.11.65.

38. Pravilnik o Listi lekova koji se propisuju i izdaju na teret sredstava obaveznog zdravstvenog osiguranja. Službeni glasnik RS 65/15; 71/15; 104/15, 24/16, 57/16, 61/16.

39. WHO Collaborating Centre for Drug Statistics Methodology. (2016). Guidelines for ATC classification and DDD assignment 2016. Oslo: World Health Organization.

40. Republički zavod za statistiku. Baza podataka. Retrieved Jun 01, 2016. from: http://webrzs.stat.gov.rs/ WebSite/public/ReportView.aspx. 